\title{
Member State Nationality, EU Citizenship and Associate European Citizenship
}

\author{
A.P. van der Mei*
}

\section{Introduction}

According to Article 20 TFEU, "[E]very person holding the nationality of a Member State shall be a citizen of the Union". ${ }^{1}$ The wording of the provision thus suggests a notably simple relationship between EU citizenship and Member State nationality: to be an EU citizen one must be a Member State national. Third country nationals cannot acquire EU citizenship. Loss of nationality implies automatic loss of this privileged status. When a Member State withdraws from the EU its nationals become third country nationals. ${ }^{2}$

From the case law of the Court of Justice of the European Union (CJEU), however, it follows that the relationship between EU and national citizenship is not as clear and straightforward as the Treaty text suggests. To be sure, the CJEU has never recognised, and not even suggested, any exceptions to the rule that EU citizenship is reserved for Member State nationals. Rather, in the wellknown Rottmann ruling, ${ }^{3}$ it confirmed the exclusive link between EU citizenship and national citizenship. What the CJEU did say in this ruling - and this is what complicates the relationship between the two citizenships - is that Member States must, before taking a decision withdrawing "their" nationality, consider the consequences of such a decision for the person concerned as regards the loss of the rights he/she enjoys as an EU citizen. Loss of EU citizenship or the rights attached to it may preclude the lawful application of national rules on deprivation of national citizenship.

* Professor of European Social law, Maastricht Centre for European Law. The author thanks Dr. Hoai-Thu Nguyen for her valuable comments on an earlier draft of this contribution. The usual disclaimer applies.

1 See also the almost identically worded Article 9 TEU.

2 The same holds true when a region or comparable entity secedes from a Member State and becomes a new independent State. See further Marrero González, G. (2017). Civis Europaeus Sum? Consequences with Regard to Nationality law and EU Citizenship Status of the Independence of a Devolved Part of an EU Member State. Oisterwijk: Wolf Legal Publishers.

3 Court of Justice, judgment of 2 March 2010, case C-135/o8, Rottmann, para. 39. 
This is not just a theoretical matter. In recent years, questions concerning the loss of Member State nationality and the implications for EU citizenship have emerged, and increasingly so, in various contexts. ${ }^{4}$ A first one concerns the fight against terrorism. Various Member States have adopted laws making it possible or easier to deprive convicted or suspected terrorists of their nationality. As commentators have observed, ${ }^{5}$ not only international law and ECHR law but also EU law, including the norms on EU citizenship, may restrict Member States law and policies on nationality deprivation. Further, in response to increased migration and the proliferation of multiple citizenship, various States have enacted laws aimed at singular citizenship. Acquisition of the nationality of a third State may result in loss of a Member State nationality and, thus, EU citizenship. In Tjebbes 6 the CJEU was given the opportunity to specify its holdings in Rottmann and to determine its significance for situations involving national fights against multiple citizenship.

And finally, there is of course Brexit. The UK's decision to withdraw from the EU has triggered numerous questions concerning the rights and interests of UK nationals. Early 2018, an Amsterdam court, in the 'Brexpats' case, ${ }^{7}$ announced its intention to ask the CJEU whether a hard Brexit indeed implies that UK nationals will become 'ordinary' third country nationals. In the end the preliminary question was not referred to Luxembourg, but Brexit and the Brexpats case do trigger interesting questions on the status and rights of nationals of former EU Member States and, more generally, the link between EU and national citizenship.

For a proper understanding of Tjebbes and the questions that arose in the case, let us first recall the lessons from Rottmann.

4 For a comprehensive overview of Member States' rules and policies on loss of nationality and its implications for EU citizenship see Carrera Nunez, S. and de Groot, G-R. (2015). European Citizenship at the Crossroads - The Role of the European Union on Loss and Acquisition of Nationality. Oisterwijk: Wolf Legal Publishers. For theoretical reflections on loss of nationality and its significance for EU citizenship see Bauböck, R. and Peskalev, V. (2015). Citizenship Deprivation - A Normative Analysis. CEPS Paper in Liberty and Security in Europe, No.82, available at www.ceps.eu.

5 See e.g. Cloots, E. (2017). The Legal Limits of Citizenship Deprivation as a Counterterror Strategy. European Public Law 23 (1), pp. 57-92.

6 Court of Justice, judgment of 12 March 2019, case C-221/17, Tjebbes and Others.

7 Rechtbank Amsterdam, C/13/640244 / KG ZA 17-1327, ECLI:NL:RBAMS:2018:605. 
First, while Member States are competent in nationality matters, they must exercise their powers with due regard for EU law. ${ }^{8}$

Second, decisions depriving a person of his or her nationality are subject to review under EU law whenever loss of EU citizenship or the rights attached to it are at stake. It is not necessary that the person concerned has exercised free movement rights. ${ }^{9}$

Third, Member States are entitled to protect the special relationship of solidarity and good faith, as well as the reciprocity of rights and duties, which form the bedrock of the bond of nationality. ${ }^{10}$

Fourth, when deciding on possibly withdrawing a nationality, Member States must observe principles of EU law, including the principles of proportionality, ${ }^{11}$ legitimate expectations and equality. ${ }^{12}$

Fifth, as regards proportionality, the CJEU demands from Member States to balance national interests, such as combatting the acquisition of their nationality by deception or fraud, against the implications of a possible withdrawal of nationality for the person concerned. ${ }^{13}$

Sixth, if proportionality is respected, Member States are entitled to withdraw nationality, which, if the person concerned does not hold the nationality of any other Member State, in turn implies the loss of EU citizenship.

In Tjebbes the Court was asked to clarify Rottmann in a case which concerned Dutch nationality law. The relevant rules stipulated that Dutch nationality is lost, by operation of law, if the person concerned also possesses a 'foreign' nationality, and has lived outside the EU for an uninterrupted period of ten years. In addition, according to the Dutch nationality rules, where a parent loses Dutch nationality on grounds of having lived in a third country for ten years, his or her minor children are deprived of Dutch nationality too, unless they would become stateless. Are these rules, so the Court was asked in Tjebbes, compatible with the Treaty provisions on EU citizenship?

\section{Adults}

Unlike the German rule at stake in Rottmann, the Dutch rule under consideration did not seek to combat wrong or fraudulent acquisition of nationality.

\footnotetext{
$8 \quad$ Rottmann, cit., paras. 39-41 and 45 .

9 Ibid., para. 42.

$10 \quad$ Ibid., para. 51.

11 Ibid., para. 55 .

12 de Groot, G-R. and Wautelet, P. (2014). Reflections on Quasi-Loss of Nationality in Comparative, International and European Perspective. CEPS Paper in Liberty and Security in Europe, No. 66, pp. 27 et seq.

13 Rottmann, cit., para. 56.
} 
Rather, the goal was to fight multi-citizenship and to ensure that nationals have and retain a genuine link with the Netherlands. Following its Advocate General, ${ }^{14}$ the Court accepted the aim of the Dutch legislature as a legally sound one:

it is legitimate for a Member State to take the view that nationality is the expression of a genuine link between it and its nationals, and therefore to prescribe that the absence, or the loss, of any such genuine link entails the loss of nationality. ${ }^{15}$

In that regard, a criterion such as laid down in Dutch legislation of residence outside national territory for a given period may be regarded as an indication that there is no such link.16 The legitimacy of this, so the Court observed, is supported by international law. For example, the European Convention on permits State parties to withdraw nationality in case of a lack of a genuine link between the State Party and a national habitually residing abroad, provided it concerns persons with double or multiple nationality, who do not run the risk of becoming stateless. ${ }^{17}$

A Member State, in principle, thus may prescribe for reasons of public interest that its nationality is lost in case of long-term residence abroad, even if this were to imply of loss of EU citizenship. The more difficult question, however, concerned proportionality. Tjebbes involved a national provision that withdraws nationality by operation of law. It should be noted that it is plain that the Dutch legislature did not blindly pursue the above-stated 'genuine linkaim'. It also had an eye on the interests of the persons concerned. The Dutch

14 Opinion of 12 July 2018, Tjebbes, cit., paras. 51-59.

15 Tjebbes and Others, cit., para. 35 .

16 Ibid., para. 36.

17 Art.7(1), sub e of the Convention. Even though the Court did not stress the point, it is worth highlighting out that the Dutch provision under consideration withdraws Dutch nationality in the event of ten years habitual residence outside not only the Netherlands but also outside the EU. The latter would seem to be crucial. If long-term habitual residence in another EU Member State could be regarded as evidence of a lack of a genuine link with the Netherlands, Dutch nationals (who also possess the nationality of a third country) could lose EU citizenship for having exercised the right to freedom of movement that they enjoy in that capacity. Exercising EU citizenship rights could therefore lead to a loss of EU citizenship. This, of course, does not and cannot hold true. De Groot, G-R. (2004). Towards a European Nationality Law. Electronic Journal of Comparative Law 8 (3), 8. Member States may impose long-term residence requirements as key elements for establishing a genuine link between them and their nationals, but, in principle, EU law and EU citizenship demand that they recognize periods of residence in another Member State as periods of residence on their own territory. 
legislature chose a quite long period of absence from the EU of ten years. It also showed flexibility: the ten-year absence rule does not apply to persons who, during this period, have lived in the Netherlands for a year or who have been issued a passport or identity card. Moreover, the rule only applies to persons who hold another nationality; the rule does not and cannot lead to statelessness. Further, and as already highlighted, the Dutch legislature showed due respect for EU law, and EU citizenship in particular, by not considering residence in another Member State as residence abroad for purposes of the ten-year rule. Finally, loss of Dutch nationality was not final and irreversible; Dutch nationals could retain it under preferential conditions.

So, the Dutch legislature did apply a proportionality test. The question that arose, however, was whether this suffices for compatibility with EU law or whether proportionality demands that all relevant factors and circumstances are taken into account in each individual case where nationality may be withdrawn. Rottmann concerned a decision in an individual case. Did the ruling in this case imply that the balancing act that proportionality entails must be performed by national authorities and/or courts in each individual case or is there room for regulatory balancing?

In the view of AG Mengozzi, a national provision may comply with the proportionality requirement, even if it is general or regulatory in nature. In support of this opinion the AG referred to the ruling in Delvigne, ${ }^{18}$ in which the Court accepted that a national provision according to which persons convicted of a crime were deprived of their right to vote, also in European Parliament elections, could pass the proportionality test. In the view of the $\mathrm{AG}$, one cannot deduce from the ruling in Rottmann a requirement that proportionality must be considered in each and every case by any administrative authority or court. This would even be at odds with the division of competences between the European Union and the Member States. It is for the Member States to govern the conditions for acquisition and loss of their nationality, and national legislatures are in principle free to establish which criteria are determinative for the genuine link between them and their nationals. If the EU principle of proportionality would require each national court in each case to consider all factors and circumstances, including those that the legislature has deliberately not chosen, determining the genuine link, it would intervene too deeply in the national domain of nationality law.

The Court did not follow its Advocate General on this point. It held that:

the loss of the nationality of a Member State by operation of law would be inconsistent with the principle of proportionality if the relevant 
national rules did not permit at any time an individual examination of the consequences of that loss for the persons concerned from the point of view of EU law. ${ }^{19}$

It follows that

the competent national authorities and courts must be in a position to examine the consequences of the loss of nationality and, where appropriate, to have the person concerned recover his or her nationality $e x$ tunc..20

That examination, so the Court explained,

requires an individual assessment of the situation of the person concerned and that of his or her family in order to determine whether the consequences of losing the nationality of the Member State concerned, when it entails the loss of his or her citizenship of the Union, might (..), disproportionately affect the normal development of his or her family and professional life from the point of view of EU law. ${ }^{21}$

As part of that examination national authorities and courts must ensure that the loss of nationality is consistent with the fundamental rights as guaranteed by the EU Charter of Fundamental Rights, and the right to respect for family life in particular. ${ }^{22}$ Circumstances that might be relevant in applying the proportionality test include difficulties in travelling Member States in order to retain genuine and regular links with members of his or her family, or to pursue professional activities, and the fact that the person concerned might not have been able to renounce the nationality of a third country. ${ }^{23}$

The Court's conclusion is notable yet understandable. Case law on the Citizenship Directive ${ }^{24}$ or the European Arrest Warrant ${ }^{25}$ demonstrate that a proportionality assessment may very well be carried out by the (European)

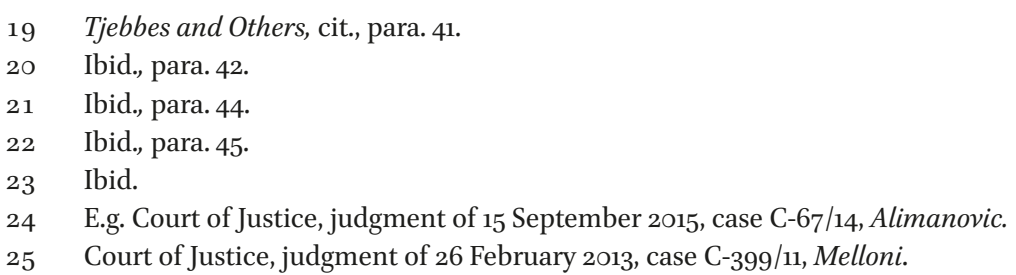


legislature without there being a need for an additional proportionality assessment by executive authorities in each individual case. ${ }^{26}$ Further, one may agree with AG Mengozzi that an obligation under EU law for national authorities and courts to check in every single case whether the legislature has sufficiently considered and balanced all factors relevant for the required genuine link is perhaps hard to compare with the duty imposed by Article 4(2) TEU on the EU to respect national identities, of which "the composition of the national body politic is clearly an essential element". ${ }^{27}$ At the same time, one certainly may have sympathy for the Court's requirement of an individual proportionality test. The application of a rule according to which a Member State nationality is lost may have very diverse implications for the right to enter or return to the European Union, a factor to which the Court appears to attach specific importance. For example, for a person who after loss of the nationality of a given Member State still holds US nationality it will be much easier than for someone who only possesses Iranian nationality. ${ }^{28}$

\section{II.2 Minor Children}

When it comes to the rules applicable to minor children, even greater doubts existed as regards the compatibility with EU law. Under these rules, Dutch children lose their nationality if the father or the mother loses Dutch nationality on the ground of having lived outside the EU for ten years or more. This holds true even if the child has lived during that period in the Netherlands or the EU. Dutch nationality is not lost if this would result in the minor child becoming stateless.

The Dutch legislature had justified this rule by emphasizing the unity of nationality within the family. The Court accepted this by holding that it is legitimate for "a Member State to wish to protect the unity of nationality within the same family". ${ }^{29}$ The Court added that the lack of a genuine link between parents (who have lived abroad for more than 10 years) and a Member State like the Netherlands can be understood, in principle, as a lack of a genuine link between the child and that same Member State. ${ }^{30}$

26 Compare the contribution by Elise Muir in this Volume.

27 Opinion in Tjebbes. cit., para. 107, referring to Opinion of AG Poiares Maduro in Rottmann, cit., para. 25 .

28 See e.g. de Groot, G-R. (2019). Beschouwingen over Tjebbes. Tijdschrift voor Asiel- \& Migrantenrecht 10 (5), pp. 196-203, 200-201.

29 Tjebbes and Others, cit., para. 35.

30 Ibid. 
However, also as regards children an individual assessment is needed of the consequences of the loss of nationality. In carrying out such an assessment, national authorities and courts must consider the development of a child's family and (future) professional life and, as Article 24(2) of the EU Charter on Fundamental Rights requires, the child's best interest must be the primary consideration. ${ }^{31}$

The Court's ruling is, in as far as children is concerned, a bit puzzling. As such it may not truly surprise that the Court accepts promoting the unity of nationality within one and the same family as a ground for justification as this indeed is an internationally recognized as a permissible tool for combating multiple nationality. ${ }^{32}$ However, it is not apparent why or how this principle of unity of nationality serves the interests of a child in cases on loss of nationality. How can depriving children of their nationality can actually promote their interests? Leaving aside issues concerning military service, one would rather think that only rights to retain or acquire nationality can serve children's interests. It is hard to see how the fact that a child possesses an additional nationality to the one that he/she shares with the parent disadvantages him/ her. ${ }^{33}$ Arguably, the interests of the child call for the promotion rather than the reduction of multiple citizenship.

Further, the Court accepted the argument of the Dutch Government that in case a parent loses his/her nationality because he/she no longer has an effective link with the Netherlands, it is reasonable to presume that also the minor children no longer have such a link. As such this presumption may make sense but not in all situations, for example in situations in which children do not live with their parent(s). Fortunately, the individual assessment and consideration of proportionality that the Court requires, may help to ensure here 'fair' outcomes in the sense that national authorities or courts may have to reach the

31 Ibid., para. 47. Compare also UN Convention on the Rights of the Child, Art. 3 (1): "In all actions concerning children, whether undertaken by public or private social welfare institutions, courts of law, administrative authorities or legislative bodies, the best interests of the child shall be a primary consideration."

32 See e.g. Second Protocol to the Convention on the Reduction of Cases of Multiple Nationality and on Military Obligations in Cases of Multiple Nationality, European Treaties Series No.149.

33 The "only conceivable disadvantage is if at a latter point in life she is suspected of terrorism - in such cases the availability of a second citizenship may expose her to deprivation, while potential statelessness may protect her from losing her preferred citizenship. However, the probability that same person is exposed to potential derivative loss as a child and threatened with deprivation on security grounds as an adult seems extremely low." Bauböck, R. and Peskalev, V., Citizenship Deprivation, cit., p. 24. 
conclusion that, unlike their parents, children cannot lose their nationality as this would affect their rights as EU citizens.

In his Opinion, the AG also criticized the Dutch rules concerned because they would disregard to the autonomous nature of EU citizenship. EU citizenship is not reserved for adults, and minors are not second-class EU citizens. Children's EU citizenship cannot be regarded as being derived from their parents' possession of that same status but must be regarded as an autonomous status. Therefore, so the AG argued, children ought to have the same procedural and substantive rights in relation to the possible loss of nationality and, thus, EU citizenship. In the case at hand, this was not the case inter alia because, under the Dutch nationality rules, only adults could break the uninterrupted period of ten years of living abroad by applying for e.g. a passport, and, by doing so, thereby retain both their nationality and EU citizenship. On this point, one does not necessarily have to agree with the AG. It may very well be true that that EU citizenship has evolved to become an autonomous status which in itself may be a source of rights, and of course, these rights can be enjoyed by all EU citizens regardless of their age. Yet, from the fact that EU law itself may determine the scope and meaning of EU citizenship rights it does not necessarily follow that it is also exclusively up to EU law to decide on who possesses EU citizenship. We will return to the issue in the following sections, but the fact is that Article 20 TFEU makes the possession of EU citizenship directly and exclusively conditional upon Member State nationality. It is not for the EU but for the Member States to determine who possesses 'their' nationality. If children's nationality derives under national law from their parents' nationality, the same holds true for EU citizenship. Both for parents and children, EU citizenship is derivative in nature. Therefore, from the autonomous nature of EU citizenship it arguably does not (necessarily) follow that children ought to have the same procedural and substantive rights as adults under national law to obtain or retain Member State nationality and, by extension, EU citizenship.

\section{Member State Withdrawal from the Union}

The Rottmann case law concerned national decisions withdrawing a Member State nationality and its implications for EU citizenship and the rights linked to that status. That case law thus is not directly applicable to situations in which a Member State nationality is lost because the Member State concerned decides to withdraw from the Union. Yet, can the logic underpinning the case law be extended to withdrawal situations? 
Early 2018 an Amsterdam district court answered this question in the affirmative. ${ }^{34}$ The court was faced with a case initiated by UK nationals living in the Netherlands, who claimed that the Dutch State and/or the city of Amsterdam had to take measures so as to ensure that they could continue to enjoy EU citizenship rights after Brexit. Referring to AG Poiares Maduro's opinion in Rottmann, ${ }^{35}$ the Amsterdam court observed that EU citizenship now constitutes an own autonomous source of rights and that decisions implying loss of Member State nationality must be proportional. The court opined that it can reasonably be doubted that loss of national citizenship implies loss of EU citizenship and stated its intention to refer the following preliminary questions to the Court of Justice:

First, does the withdrawal of the UK from the EU automatically lead to the loss of EU citizenship of [UK] nationals and, thus, to the elimination of rights and freedoms deriving from EU citizenship, if and in so far as the EU and the UK do not agree otherwise in the exit-negotiations?

Second, if Brexit does imply loss of EU citizenship, should conditions or restrictions be imposed on the maintenance of the rights and freedoms to be derived from EU citizenship? In the end, however, the questions were not referred to Luxembourg. ${ }^{36}$

It is not clear on what grounds the Amsterdam court based its suggestion that UK nationals might keep EU citizenship after Brexit. It may very well be that EU citizenship has evolved to become a fundamental status that may constitute an autonomous source of EU rights, and that Article 20 TFEU "precludes

34 Rechtbank Amsterdam, C/13/640244 / KG ZA 17-1327, ECLI:NL:RBAMS:2018:605. See also Garner, O. (2018). Does Member State Withdrawal from the European Union Extinguish EU Citizenship? European Law Blog, available at: http://europeanlawblog.eu/2018/o2/19/ does-member-state-withdrawal-from-the-european-union-extinguish-eu-citizenshipc13640244-kg-za-17-1327-rechtbank-amsterdam-the-amsterdam-case.

35 Ibid., para. 5.20.

36 The Amsterdam court had not yet taken the decision to refer the question to the Court of Justice. It had invited the parties in the proceedings to appeal its interlocutory decision before the Court of Appeals. The Court of Appeals recognized that a decision to refer preliminary questions cannot be made subject to an appeal (Court of Justice, judgment of 16 December 2008, case C-210/o6, Cartesio), but held that it nonetheless had jurisdiction because parties could appeal the interlocutory decision also on grounds other than the decision to refer preliminary questions. The Court of Appeals shared the view that doubts indeed exist as regards the view that Brexit implies loss of EU citizenship, but it concluded that the British applicants' claims were too vague. Regardless of the possible answers of the Court of Justice to the suggested preliminary question, applicants had not adequately indicated what concrete measures they demanded to be taken by the State and city. Gerechtshof Amsterdam, 2000.235.073/o1 SKG, ECLI:NL:GHAMS:2018:2009. 
national measures which have the effect of depriving citizens of the Union of the genuine enjoyment of the substance" 37 of EU citizenship rights. From that, however, no conclusion can be drawn about a possible retention of EU citizenship itself after a Member State has left the EU. One could perhaps seek to interpret Article 20 TFEU to imply that Member States - via their nationality laws - can only decide on the grant but not on the withdrawal of EU citizenship, but there is not much, if anything, in the text or drafting history to support this reading. ${ }^{38}$ Further, it is hard to understand why or how the Court's line of reasoning in Rottmann can be extended to situations in which a Member State national loses his/her nationality as a result of the decision of his/ her Member State to step out of the Union. Should, because of Rottmann, a Member State observe proportionality when taking a decision under Article 50 TEU? A decision to withdraw nationality in individual cases and a decision to withdraw as an entire State from the European Union are not in any serious manner comparable. The entire reasoning of the Court was clearly geared towards the specific individual situation in which Mr. Rottmann found himself. It simply does not make much sense to draw conclusions from this reasoning for the entirely different situation of Brexit, in which millions of citizens could lose EU citizenship as a result of a collective decision adopted in accordance with their own democratic rules.

Article 20 TFEU makes it patently clear that EU citizenship is derivative in nature. Neither in Rottmann nor in any other ruling did the Court cut through EU citizenship's exclusive and absolute link with Member State nationality. From existing case law one arguably can only draw one logical conclusion: for UK nationals, Brexit implies loss of EU citizenship.

Of course, (some) UK nationals might have hoped for an activist Court that would be willing to change its position. ${ }^{39}$ There are no sound reasons, however, why the Court would or should have done so. The contrary rather holds true. If the Court would have accept that nationals of former Member States could retain EU citizenship, it would have acted contrary to the wishes of the drafters of the Treaty.

First, in Maastricht the drafters made it patently clear that it is not the Union but the Member States who, through their nationality laws, decide on

37 Court of Justice, judgment of 8 March 2011, case C-34/o9, Ruiz Zambrano, para. 43.

38 Compare Dawson, M. and Augenstein, D. (2016). After Brexit: Time for a Further Decoupling of European and National Citizenship. Verfassungsblog, available at https:// verfassungsblog.de/brexit-decoupling-european-national-citizenship.

39 Compare Shaw, J. (2018). EU Citizenship: Still a Fundamental Status? EUI Working Paper RSCAS 2018/14, pp. 10-11. 
who holds EU citizenship. Second, in Lisbon, by including Article 50 in the TEU and by thus ordering the EU to negotiate and conclude an agreement governing the arrangements for withdrawal with the exiting Member State, the drafters of the Treaty made it clear that a possible retention of EU citizenship and of the rights linked to it falls within the tasks of the political EU institutions, not of the Court. The entire structure of Article 50 TEU implies that it is up to Member States to withdraw from the Union in whichever manner they wish; EU law does not impose any limitations as to the reasons for the withdrawal, the manner in which this decision is taken, or the extent to which that Member State takes into consideration the interests of its own nationals. If a Member State decides to withdraw from the EU, and thus to deprive their nationals of EU citizenship, it is perfectly entitled to do this. The EU, including its highest court, cannot alter this.

\section{3}

\section{Associate EU Citizenship}

Thus, under the Treaties, it essentially falls to the EU political institutions rather than the Court to prevent a situation in which UK nationals would lose EU citizenship status and/or rights as a consequence of Brexit. As regards the possibilities and options available, politicians, ${ }^{40}$ non-governmental organisations ${ }^{41}$ as well as academics have expressed their views. ${ }^{42}$ The most interesting ones among the suggested proposals were those calling for the introduction of an associate EU citizenship. The original idea, if I am correct, stemmed from the mind of the European Parliament's Brexit coordinator, Guy Verhofstadt. In December 2016, Verhofstadt suggested a form of EU 'associate citizenship' status that would allow individuals to "keep free movement to live and work across the EU, as well as a vote in European Parliament elections". MEP colleague Goerens supported the idea and added that "[f]ollowing the reciprocal

40 These include meps Goerens and Verhofstadt. See further Miller, V. (2018) Brexit and European Citizenship, House of Commons - Briefing paper 8365, and Austin-Greenall, A. and Lipinska, S. (2017). Brexit and Loss of EU Citizenship: Cases, Options, Perceptions, Citizen Brexit Observatory.

41 See e.g. the various European citizens' initiatives Permanent European Union Citizenship, Retaining European Citizenship and EU Citizenship for Europeans: United in Diversity in Spite of jus soli and jus sanguinis, available on http://ec.europa.eu/citizens-initiative/public/welcome. See further the contribution by Natassa Athanasiadou in this Special Issue.

42 See Kostakopoulou, D. (2018). Scala Civium: Citizenship Templates Post-Brexit and the European Union's Duty to Protect EU Citizens. Journal of Common Market Studies 56(4), pp. 854-869. 
principle of 'no taxation without representation', these associate citizens should pay an annual membership fee directly into the EU budget." ${ }^{\prime 3}$ The EP itself was also sympathetic to the idea and proposed that the EU-27 would examine how to mitigate the loss of EU rights by UK nationals by introducing such status, provided that full respect is given to the principles of reciprocity, equity, symmetry and non-discrimination. ${ }^{44}$

The idea of an associate EU citizenship has proven to be controversial, with some indeed advocating it ${ }^{45}$ and others (strongly) opposing it. ${ }^{46}$ Discussions on this status are not always easy to understand, partly because it is not truly clear what associate European citizenship would actually entail. To be sure, associate European citizenship would differ from EU citizenship itself. Those who favour it do not seem to call for a retention of the status established by Article 20 TFEU but rather for the creation of a new status. Further, it would be a status to be granted or offered to nationals of former Member States and not, for example, to third country nationals who have acquired long-term residence status. Third, in terms of substance, the new status would encompass the most important EU citizenship rights: free movement rights (presumably including equal treatment) and active voting rights in European Parliament elections.

Numerous aspects, however, still remain unclear. For example, will/would paying a fee into the EU budget be a requirement, as MEP Goerens suggested? The issue certainly is relevant for the legitimacy of Associate citizenship and reminds us of the 'citizenship-by-investment' of Malta, and a few other Member States. ${ }^{47}$ The Maltese programme has proven quite controversial inter alia because of a free rider problem. By buying Maltese citizenship, a country with which they may have no genuine link, third country nationals could acquire EU citizenship and, subsequently, move to other Member States, which otherwise would never have admitted them. This free rider problem would not exist

43 Goerens, C. (2016). European Citizenship, Blog, available at https://www.charlesgoerens. eu/blog-charles/eu-citizenship.

44 European Parliament, Draft Motion for a Resolution to to wind up the debate on negotiations with the United Kingdom following its notification that it intends to withdraw from the European Union, 29 March 2017, B8-0ooo/2017.

45 For an overview see Austin-Greenall, A. and Lipinska, S. (2017). Brexit and Loss of EU Citizenship, cit.

46 Kochenov, D. (2018). Misguided 'Associate EU Citizenship' - Talk as a Denial of EU Values. Verfassungsblog, available at https://verfassungsblog.de/misguided-associate-eucitizenship-talk-as-a-denial-of-eu-values/, and Van den Brink, M. and Kochenov, D. (2019). Against Associate EU Citizenship.Journal of Common Market Studies 57 (6), pp. 1366-1382.

47 Carrera, S. (2014). The Price of EU Citizenship - The Maltese Citizenship-for-Sale Affair and the Principle of Sincere Cooperation in Nationality Matters. Maastricht Journal of European and Comparative Law 21 (3), pp. 406-427. 
if one were to introduce associate citizenship at EU level. Yet, is it desirable to ask a price for a citizenship-like status, to commercialise it? Will it be a new status based on a genuine link that its holders have with the EU or one of its Member States, or will associate EU citizenship be a tradable good?

A next question that then arises is who would be the beneficiaries of this new associated citizenship? Concretely in the case of Brexit: would only the Brits who have moved to another Member State and have lived there for a given period of time be given the right or option to become associate EU citizens, or also those who have never done so and find themselves in 'purely internal British situation'? The answer to this question is relevant because it triggers the subsequent question of what the actual aim of associate citizenship would be: is it just a means to ensure the continuation of rights for nationals of exiting Member States living in other EU Member States, or does it have an own intrinsic or more deeply motivated aim? If the former is the case, why would UK nationals who have never settled across the Channel still need to have a right to vote for the EP? Those who wish to include EP election rights for this category of UK nationals must have something else or more in mind. Yet, what exactly? Even though the term 'associate citizenship' is used, is it not that this is meant as a covert way to make sure that Brits, and potential other future exMember State nationals, can nonetheless retain EU citizenship?

It is of course perfectly possible that advocates of associate European citizenship themselves do not exactly know what they are proposing or what the implications of their proposal might be. As noble as their motives may be, if these advocates have more in mind than merely freezing the legal status of UK nationals living in 'Europe', one must be cautious. Critical questions must be addressed. If this envisaged status is meant as a status separate from EU citizenship, yet encompassing the same or very similar rights as the latter, does it not undermine EU citizenship? Even if it were established that the EU can formally confer all rights that it offers to its own citizens to third country nationals, does the very existence of EU citizenship not command restrictions? Further, and recalling what has previously been said about Article 50 TEU, why is there at all a need for the EU to consider introducing a new status to the benefit of people who have collectively, and fully in accordance with their own internal constitutional norms and procedures, decided to step out of the Union and decided to give up their EU citizenship? Apparently, the majority who voted in favour of Brexit did not consider EU citizenship important enough. And whatever others may think of this choice, the choice to leave the EU made was entirely legally. Those who voted to remain simply have to accept that they, as a result of UK constitutional rules, lost the battle and, with that, EU citizenship and all rights flowing from this status. In fact, by offering one-sidedly associate 
citizenship to those UK nationals who wish to remain part of the European integration project, the EU is meddling in the internal affairs of a former Member State in which it arguably should not meddle.

Finally, and perhaps most importantly, why would the EU at all consider unilaterally offering a new status to British (or other former EU) citizens without there being any reciprocal status or legal protection for EU citizens living in the UK (or any other exiting Member State)? The number of EU citizens in the UK far exceeds the number of UK nationals living in 'Europe'. As noble as it may be to show legal and political compassion with UK nationals in EU-27 Member States, the EU's main commitment does not, or at least should not, lie with them but rather with EU citizens living in the UK. The EU should not give in to the pressure of all those who - often quite annoyingly - place so much emphasis on the negative implications of Brexit for UK nationals living in the EU without giving equal (if any at all) attention to the rights and interests of EU citizens residing in the UK. Reciprocity is a must. Without it, introducing associate European citizenship is an idea that is doomed to be rejected by EU citizens.

\section{$4 \quad$ Final Remarks}

There is no denying that the drafters of the European Treaties have decided to reserve EU citizenship for nationals of EU Member States. The Court of Justice has never cut through the exclusive link between Member State nationality and EU citizenship. As the legal situation stand at present, the Court is well advised not to alter its position just because of 'Brexit'. If it were to do so, it would likely be faced with accusations of undue judicial activism that may not be easy to dismiss.

Of course, one fully understands the frustrations of all those UK nationals who live in 'Europe' and may lose the rights attached to EU citizenship, or all those British citizens who voted for 'Bremain'. And, yes, one understands the calls made by them, or on their behalf, for cutting through the umbilical cord between EU and national citizenship. Yet, this is not a task for the Court, but rather a task for 'politics' and, more concretely, for the parties that have to negotiate the exit agreement under Article 50 TEU. One may dislike the idea that individuals are subject to political negotiations and thus deals, ${ }^{48}$ but that is essentially what the Treaty prescribes. Given their political, day-to-day nature 
one can only be satisfied that the Brexit-negotiators have limited themselves to a freezing of the rights of mobile EU citizens and have not burned their fingers on more fundamental questions concerning the scope and nature of EU citizenship. For an answer on those questions we, as European citizens, need to take more time to reflect. 